\title{
Efficient Extraction and Some Properties of Storage Proteins (Prolamin and Glutelin) in Ancient Rice Cultivars
}

\author{
Junko Udaka, ${ }^{1}$ Tetsuro Koga, ${ }^{2}$ Hideaki TsujI, ${ }^{3}$ Masumi Kimoto ${ }^{3}$ and Kenji TakUmi ${ }^{4}$ \\ ${ }^{1}$ Laboratory of Food Science, Faculty of Education, Ehime University, \\ Matsuyama, Ehime 790-8577, Japan \\ ${ }^{2}$ Department of Nutrition, School of Medicine, University of Tokushima, \\ Tokushima, Tokushima 770-0042, Japan \\ ${ }^{3}$ Department of Nutritional Science, Faculty of Health and Welfare, \\ Okayama Prefectural University, Sojya, Okayama 719-1197, Japan \\ ${ }^{4}$ Department of Food and Nutrition, Okayama Women's College, \\ Kurashiki, Okayama 710-8511, Japan
}

(Received September 14, 1998)

\begin{abstract}
Summary Two typical storage proteins (prolamin and glutelin) in a total of 14 samples of ancient rice cultivars were examined for their accumulation in the endosperms during days after flowering (DAF), extraction efficiency with various solvents, and variations in polypeptide components or amino acid compositions. There was little difference in accumulation profiles between this and previous observations, in which glutelin appeared on 5-7 DAF and prolamin on 7-9 DAF. As for the extraction of prolamin and glutelin, it was most effectively attained by sequential usage of $55 \%$ propanol and $2 \%$ SDS. As a result of SDSPAGE, prolamin and glutelin proved to be composed mainly of a single polypeptide with a molecular weight (MW) of $15 \mathrm{kDa}$ and two subunits with MWs of $21 \mathrm{kDa}(\alpha)$ and $32 \mathrm{kDa}$ $(\beta)$, respectively. A comparison between the ancient and modern rice cultivars revealed the same physicochemical properties in either case of prolamin or glutelin. Additionally, a good relationship was observed on the total protein and glutelin (but not prolamin) contents in the ancient rice cultivar.
\end{abstract}

Key Words ancient rice cultivar, storage protein, prolamin, glutelin, efficiency of protein extraction

Ancient rices, wild form Oryza sativa L., indigenous to various districts of Japan are now potential sources requisite for genetic improvement in nutritional quality (1) and allergenicity (2). They have received only limited attention for their basic physicochemical characteristics $(3,4)$. Storage proteins in most cereals are usually composed of prolamin and glutelin (5). As for rice grains, glutelin predominant in storage proteins comprises more than $80 \%$ of the total proteins, of which several percent are exchanged for prolamin (6). However, these contents are significantly variable according to rice cultivars $(7,8)$ or extraction procedures $(9,10)$. The extraction conditions affect not only the recovery of total proteins, but also their polypeptide components (11).

Although we have referred to ancient rice proteins in a preceding report (12), their extraction efficiencies and characteristics have not been investigated so much. To understand the biochemical properties of ancient rice proteins further, we aimed at finding the most effective and reproducible extraction procedure, and thereby elucidated some features of storage proteins in ancient rice grains.

In this paper, we describe the extraction efficiency of storage proteins with solvents, the protein accumulation in seed after flowering, and the multiplicity of polypeptide components of storage proteins on the basis of comprising a total of 14 samples of ancient rice grain with modern rice cultivars.

\section{MATERIALS AND METHODS}

Rice seeds (Oryza sativa L.). Fourteen kinds of ancient rice cultivars including Midorimai, Benimiyako, Takaramitsu, Kaori-eigou, Kaori-mochi, Benihikari, Akitakuro, Kunitsukasa-chukann, Mangetsu-mochi, Kuro-mochi, Kuro-60, Tsushimazairai, Murasaki-kuro, Kuro-73 and nine kinds of modern rice cultivars including Koshihikari, Akitakomachi, Kinuhikari, Hiyoku-mochi, Takasagomochi, Aizen-mochi, Nobentadiablanco, Mitsuyou-23 and Bluebonnet were supplied by Uwa Rice Museum (Uwacho, Ehime 797-0015, Japan) as described previously (12). The rice seeds were dehulled and milled by a motor machine, ground into a 60-mesh flour, stirred twice with acetone for $5 \mathrm{~h}$ at room temperature, and air-dried.

Assay for seed protein accumulation. Japonica Kuromochi and Tsushimazairai (ancient rice cv.) were pot-cultured between June and late October in 1995 at the Laboratory of Food Science in the Faculty of Education at Ehime University (Matsuyama, Ehime 790-8577) as reported previously (12). The individual panicles were tagged at mid-panicle when anthesis occurred. After flowering, the developing panicles were harvested at in- 
Table 1. Efficiency ${ }^{\mathrm{a}}$ of prolamin extraction from ancient and modern rice cultivars with 4 aqueous-alcohols. ${ }^{\mathrm{b}}$

\begin{tabular}{|c|c|c|c|c|c|}
\hline $\begin{array}{c}\text { Rice } \\
\text { cultivars }\end{array}$ & $\begin{array}{c}70 \% \\
\mathrm{E}-\mathrm{OH}\end{array}$ & $\begin{array}{c}55 \% \\
\mathrm{P}-\mathrm{OH}\end{array}$ & $\begin{array}{c}60 \% \\
\mathrm{iP}-\mathrm{OH}\end{array}$ & $\begin{array}{c}55 \% \\
\text { tB-OH }\end{array}$ & $\begin{array}{c}\text { Total } \\
\text { protein } \\
(\%)^{\mathrm{c}}\end{array}$ \\
\hline Kaori-mochi & 1.86 & 4.18 & 2.79 & 4.07 & 8.45 \\
\hline Kunitsukasa-chukann & 3.14 & 7.40 & 4.37 & 4.93 & 8.87 \\
\hline Kuro-mochi & 2.39 & 7.80 & 4.89 & 3.64 & 9.58 \\
\hline Kuro-60 & 3.92 & 5.16 & 4.33 & 4.54 & 9.64 \\
\hline Tsushimazairai & 2.54 & 4.73 & 3.33 & 3.06 & 11.36 \\
\hline Hiyoku-mochi ${ }^{\mathrm{d}}$ & 1.44 & 3.27 & 1.57 & 2.75 & 7.56 \\
\hline Nobentadiablanco $^{\mathrm{d}}$ & 1.62 & 4.37 & 2.49 & 3.24 & 7.91 \\
\hline Koshihikari $^{\mathrm{d}}$ & 1.71 & 5.49 & 1.83 & 2.56 & 8.15 \\
\hline Akitakomachi $^{\mathrm{d}}$ & 1.18 & 3.01 & 1.51 & 2.80 & 9.22 \\
\hline Mitsuyou-23 $3^{\mathrm{d}}$ & 1.65 & 3.94 & 2.84 & 3.30 & 10.71 \\
\hline
\end{tabular}

${ }^{\text {a }}$ Data are the means of triplicate determinations.

b $70 \%$ ethanol (E-OH), 55\% propanol (P-OH), 60\% isopropanol (iP-OH), 55\% tert-butanol (tB-OH).

${ }^{c}$ Percent on a dry weight basis.

${ }^{\mathrm{d}}$ Modern rice cultivars.

tervals of 3 or $4 \mathrm{~d}$ during a period of $40 \mathrm{~d}$ after flowering (DAF). The harvested panicles were immediately frozen at $-20^{\circ} \mathrm{C}$ until analysis by SDS-PAGE.

Extraction of prolamin and glutelin. The respective defatted rice flours from 10 cultivars (Table 1 ) were suspended with 10 volumes $(\mathrm{v} / \mathrm{w})$ of $20 \mathrm{~mm}$ phosphate buffer ( $\mathrm{pH} 7.3$ ) containing $0.5 \mathrm{M} \mathrm{NaCl}$ and stirred for $2 \mathrm{~h}$ at room temperature. After centrifugation at $21,000 \times g$ for $20 \mathrm{~min}$, the pellets were washed twice with water and freeze-dried. Then, prolamin was extracted as follows: the salt-insoluble pellets were separately stirred with 10 volumes $(\mathrm{v} / \mathrm{w})$ of aqueous alcohols such as $70 \%$ ethanol, $55 \%$ propanol, $60 \%$ isopropanol, and $55 \%$ tert-butanol for $1 \mathrm{~h}$ at room temperature, and centrifuged at $21,000 \times g$ for $20 \mathrm{~min}$ at $4^{\circ} \mathrm{C}$. The supernatants were dialyzed against tap water for $48 \mathrm{~h}$ and against distilled water overnight. Prolamin fractions were obtained as pellets by centrifugation. These prolamins were washed twice with water, freezedried and kept at $-20^{\circ} \mathrm{C}$.

The aqueous alcohol-insoluble pellet was washed three times with acetone and air-dried. The pellet thus obtained was looked upon as crude glutelin. The precipitation of glutelin was done as follows: the crude glutelin preparations from Koshihikari, Tsushimazairai and Hiyoku-mochi were stirred with 10 volumes $(\mathrm{v} / \mathrm{w})$ of $2 \% \mathrm{SDS}$ and/or $5 \mathrm{M}$ urea with or without 2 -mercaptoethanol (2-ME) or 10 volumes $(\mathrm{v} / \mathrm{w})$ of $0.1 \% \mathrm{NaOH}$ or $0.05 \%$ acetic acid for $1 \mathrm{~h}$ (but $30 \mathrm{~min}$ in the case of urea) at room temperature. The extracts were centrifuged at $21,000 \times \mathrm{g}$ for $20 \mathrm{~min}$ at $4^{\circ} \mathrm{C}(0.05 \%$ $\mathrm{CH}_{3} \mathrm{COOH}$ or $\left.0.1 \% \mathrm{NaOH}\right)$ or $15^{\circ} \mathrm{C}(2 \% \mathrm{SDS}$ and/or $5 \mathrm{M}$ urea). The supernatants were neutralized and dialyzed against distilled water overnight and the resulting glutelin precipitates were freeze-dried and kept at $-20^{\circ} \mathrm{C}$. Supernatants of the SDS and urea extracts were mixed with two volumes of acetone and allowed to stand for several hours at room temperature. The resulting glutelin sediments were washed three times with acetone, air-dried and stored at $-20^{\circ} \mathrm{C}$.

SDS-PAGE and two-dimensional gel electrophoresis (2$D E)$. SDS-PAGE was done with 15 or $25 \%$ polyacrylamide gels prepared essentially according to the method of Laemmli (13). The gels were stained with Coomassie blue R250 and destained with 10\% acetic acid-20\% isopropanol. 2-DE was done according to the method of O'Farrel et al. (14), in which DE was first conducted by electrofocusing with ampholine (Pharmacia) at a $\mathrm{pH}$ of 3.5-10 in a vertical column $(90 \times 2 \mathrm{~mm})$ and secondly by SDS-PAGE with $15 \%$ polyacrylamide gel.

Chemical analysis. Protein was determined by the micro-Kjeldahl method with the conversion factor of 5.95 (15), or by Lowry's method (16) using bovine serum albumin as the standard. Amino acid composition was determined with a Hitachi 835 amino acid analyzer after acid hydrolysis in the usual way.

\section{RESULTS AND DISCUSSION}

Accumulation profiles of storage proteins in ancient rice cultivars

We first tried to study the maturing process of rice seed proteins in the endosperm. For this reason, the profiles of storage protein accumulation during the grain-filling period of Kuro-mochi and Tsushimazairai were analyzed by SDS-PAGE (Fig. 1A and B). On about 5 DAF, several distinct polypeptides with MWs of 52,32 , 21 , and $15 \mathrm{kDa}$ appeared. It has been reported by Kim et al. (17) that rice protein accumulation occurs between 3 and $8 \mathrm{DAF}$, accompanied with a dramatic increase in 32, 21 and $15 \mathrm{kDa}$. These accumulation profiles were also identical to the findings of Yamagata et al. (18), Luthe (19) and Zhao et al. (20), indicating that both 32 and $21 \mathrm{kDa}$ subunits corresponded to rice glutelin $\alpha$ and $\beta$, respectively. The $15 \mathrm{kDa}$ corresponded to rice prolamin, which was apparently one of the major polypeptides in Kuro-mochi (Fig. 1A), while Tsushimazairai showed two prolamin species with MWs of 15 and $13 \mathrm{kDa}$ (Fig. 1B). A similar variation was also reported by Ogawa et al. (9), who observed that prolamin was composed of three subunits with MWs of 10 , 13 , and $16 \mathrm{kDa}$ in Nihonsakari. It remains to be further investigated whether or not prolamin is inherently monomeric or polymeric.

Extraction efficiency of prolamin and glutelin from various rice seeds

The efficiency of extracting prolamin preparations from 5 ancient rice cultivars and 5 modern ones with 4 kinds of aqueous alcohols are compared in Table 1. Although there was a wide range of total protein contents $(7.6-11.4 \%)$ among the cultivars, the most efficient was $55 \%$ propanol, by which $3.3-7.8 \%$ of the total protein was extractable. With $55 \%$ tert-butanol, $2.6-4.9 \%$ of the total protein was extracted. Neither $70 \%$ ethanol nor $60 \%$ isopropanol was very efficient in the extraction of rice prolamin. Shewry and Miflin (5) 
have referred to $50 \%$ propanol $>55 \%$ isopropanol $>60-$ $70 \%$ ethanol in order of extraction efficiency. Sugimoto et al. (10) demonstrated that 55\% propanol was the most effective in the extraction of rice prolamin among 5 kinds of aqueous alcohols. SDS-PAGE of prolamin preparations from Kuro-mochi by the 4 kinds of aqueous alcohols revealed only one polypeptide component with a MW of $15 \mathrm{kDa}$ (Fig. 2), suggesting that the $15 \mathrm{kDa}$

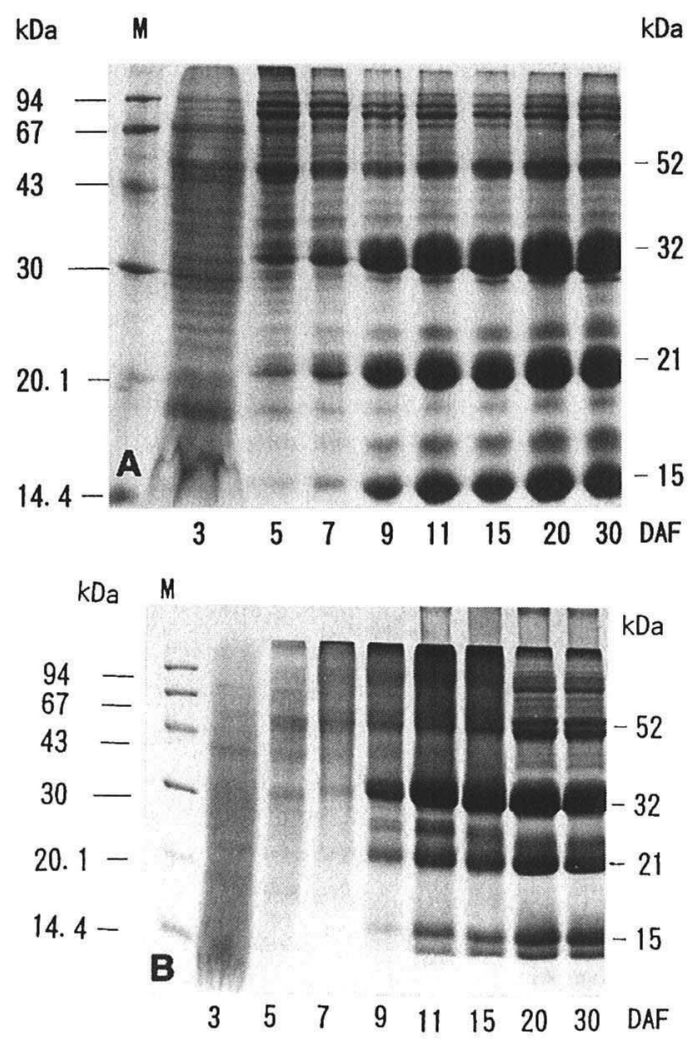

Fig. 1. Accumulation profiles of the storage proteins during the development of seeds of ancient rice cultivars. Kuro-mochi (A) and Tsushimazairai (B). Numbers at the bottom represent the days after flowering (DAF). M lane, marker proteins. MWs at both ends. subunit was in common with the aqueous alcohol-soluble "prolamin" component.

Crude glutelin preparations were obtained from 3 cultivars different in protein content (in \%): Tsushimazairai (11.4), Koshihikari (8.2) and Hiyokumochi $(7.6 \%)$. Glutelin was extracted with the various solvents shown in Table 2 . More than $87 \%$ of the total protein could be extracted with $\mathrm{NaOH}, \mathrm{SDS}$, SDS+2-ME or SDS+urea+2-ME; above all, a combination of $2 \%$ $\mathrm{SDS}+5 \mathrm{M}$ urea+0.5\% 2-ME was the most effective in glutelin extraction from 3 rice cultivars, which was actually improved slightly by the addition of 2-ME. Cereal glutelin fractions usually contain starch, which gelatinizes the cereal sample in the presence of urea and thereby makes the glutelin unextractable $(21,22)$.

SDS-PAGE patterns about glutelin from these ancient rices are compared in Fig. $3 \mathrm{~A}$ and $\mathrm{B}$. In panel $\mathrm{A}$, SDSPAGE of the extracts with $2 \%$ SDS (lane 1), $2 \%$ SDS+ $0.5 \%$ of $2-\mathrm{ME}$ (lane 3 ) and $0.1 \% \mathrm{NaOH}$ (lane 5 ) demonstrated that glutelin was composed of two major polypeptides with MWs of 32 and $21 \mathrm{kDa}$ as described

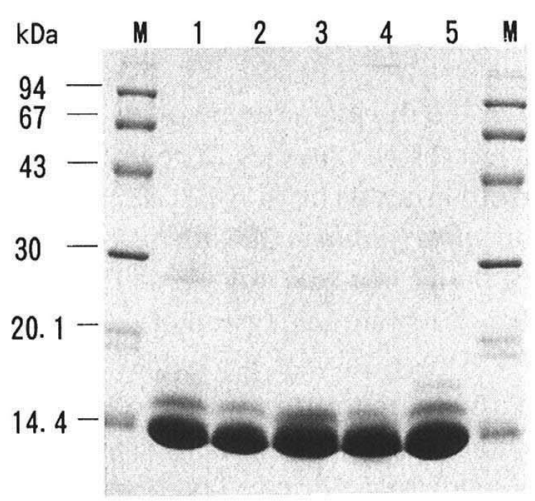

Fig. 2. SDS-PAGE of prolamin fraction extracted from ancient rice cultivars Akita-kuro with aqueous alcohols. 55\% propanol (lanes 1 and 5); 70\% ethanol (lane 2); $60 \%$ isopropanol (lane 3); and 55\% tert-butanol (lane 4).

Table 2. Efficiency ${ }^{\mathrm{a}}$ of glutelin extraction from ancient and modern rice cultivars with 7 solvents. ${ }^{\mathrm{b}}$

\begin{tabular}{|c|c|c|c|}
\hline Solvent $^{\mathrm{c}}$ & Tsushimazairai & Koshihikari $^{d}$ & Hiyoku-mochi $^{\mathrm{d}}$ \\
\hline Total protein content $(\%)^{\mathrm{e}}$ & 11.4 & 8.2 & 7.6 \\
\hline \multicolumn{4}{|c|}{ Extractive efficiency (\% of total protein) } \\
\hline $2 \% \operatorname{SDS}$ & 88.3 & 87.0 & 87.6 \\
\hline $2 \% \operatorname{SDS}+0.5 \% 2-\mathrm{ME}^{\mathrm{f}}$ & 91.6 & 90.2 & 88.3 \\
\hline 5 м Urea & 2.7 & 3.5 & 2.5 \\
\hline $5 \mathrm{~m}$ Urea $+0.5 \% 2-\mathrm{ME}^{\mathrm{l}}$ & 16.1 & 17.1 & 16.5 \\
\hline $2 \% \operatorname{SDS}+5 \mathrm{~m}$ urea $+0.5 \% 2-\mathrm{ME}^{\mathrm{f}}$ & 92.2 & 92.0 & 91.2 \\
\hline $0.1 \% \mathrm{NaOH}$ & 94.2 & 92.0 & 88.3 \\
\hline $0.05 \% \mathrm{CH}_{3} \mathrm{COOH}$ & 0.5 & 0.4 & 0.5 \\
\hline
\end{tabular}

\footnotetext{
${ }^{\text {a }}$ Data are the means of triplicate determinations.

${ }^{\mathrm{b}}$ Insoluble pellets after extraction with $0.5 \mathrm{M} \mathrm{NaCl}-55 \%$ propanol were dissolved in each solvent at a final concentration of $\mathrm{g} / 10 \mathrm{~mL}$ by stirring for $60 \mathrm{~min}$ at room temperature and treated as described in Materials and Methods.

${ }^{\mathrm{c}}$ Solvents containing SDS (2\%) and/or urea ( $\left.5 \mathrm{M}\right)$ were dissolved in $10 \mathrm{~mm}$ Tris/HCl buffer of $\mathrm{pH} 8.5$.

${ }^{\mathrm{d}}$ Modern rice cultivars.

${ }^{\mathrm{e}}$ On a dry weight basis.

'2-Mercaptoethanol.
} 
previously (18-20). In panel B, however, SDS-PAGE of the extracts and pellets with acetic acid (lane 1) and urea (lane 3) displayed not the vary extracts but insoluble pellets gave glutelin components much more (lanes 2 and 4). Protein was more effectively extracted with a

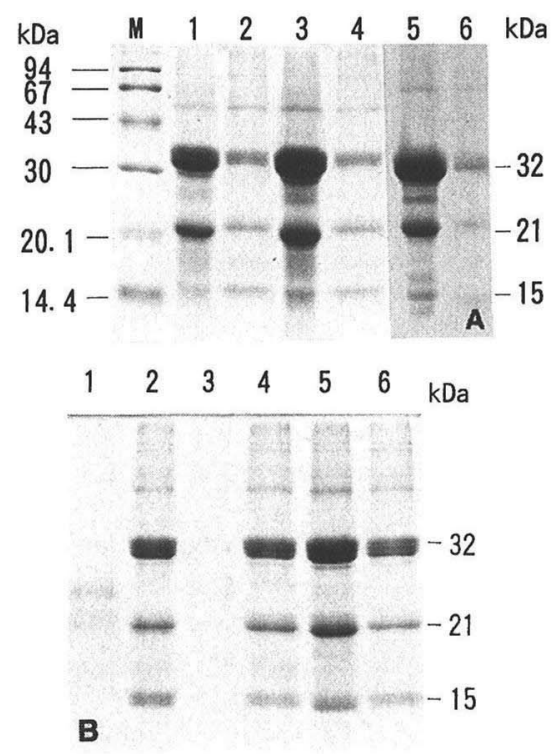

Fig. 3. SDS-PAGE of glutelin fraction extracted from ancient rice Akita-kuro with various solvents. The crude glutelin pellets, after removal of prolamin, were suspended in 10 volumes and stirred for $60 \mathrm{~min}$ at room temperature. Aliquots of the supernatants (odd numbers) were applied to SDS-PAGE plate. The insoluble residues were redissolved for $5 \mathrm{~min}$ in boiled buffer and their supernatants were used (even numbers). A: lanes 1 and 2, 2\% SDS; lanes 3 and 4, 0.1\% NaOH; lanes 5 and $6,2 \%$ SDS $+5 \mathrm{~m}$ urea $+0.5 \%$ 2-ME. B: lanes 1 and 2, 0.05\% acetate; lanes 3 and $4,5 \mathrm{~m}$ urea; lane 5, 2\% SDS + $5 \mathrm{M}$ urea $+0.5 \% 2-\mathrm{ME}$; lane 6 , the supernatant of $5 \mathrm{M}$ urea $+0.5 \% 2-\mathrm{ME}$. combination of SDS and urea (lanes 5), only reflecting efficiency with SDS. Consequently, the addition of $2 \%$ SDS to a $10 \mathrm{~mm}$ Tris/HCl buffer of $\mathrm{pH} 8.5$ was considered useful for the extraction of glutelin from ancient rice. Although $0.1 \% \mathrm{NaOH}$ seemed more effective than $2 \%$ SDS, its use brought about degradation of the sample proteins (5).

To confirm whether SDS-PAGE patterns for the 15 $\mathrm{kDa}$ prolamin and two glutelin polypeptides hold true to other ancient rice cultivars, 55\% propanol-soluble prolamin and $2 \%$ SDS-soluble glutelin were sequentially prepared from 14 rice cultivars ( 8 ancient and 6 modern rice lines) and judged by SDS-PAGE. As shown in Fig. $4 \mathrm{~A}, 10$ cultivars contained a major $15 \mathrm{kDa}$ subunit with or without a minor one (lanes 3-7, 9-11, 13-15), while 4 cultivars provided double bands equal in amount (lanes 2, 8, 12, 13). Horikoshi et al. (23) have demonstrated that Nihonbare prolamin consists of a single polypeptide (131 residues) with a MW of 14,930 . Li and Okita (8) have isolated the gene coding $15 \mathrm{kDa}$ prolamin from rice line M201. These data suggest that the $15 \mathrm{kDa}$ prolamin is a common component occurring in both ancient and modern rice cultivars. Likewise, SDSPAGE profiles of the 14 samples of glutelin revealed that glutelin was comprised mainly of two subunits, $\alpha$ and $\beta$, in common with ancient and modern rice cultivars (Fig. 4B).

Physicochemical properties of the major components of 55\% propanol-soluble prolamin and $2 \%$ SDS-soluble glutelin

Horikoshi et al. (23) previously demonstrated that Nihonbare $15 \mathrm{kDa}$ prolamin gave five bands with PIs of 5.6, 7.1, 7.3, 7.6, and 7.8 on isoelectricfocusing. This profile was exactly like that reported by Padhye and Salunkhe (24). In this connection, Akita-kuro prolamin was purified by preparative SDS-PAGE (25) and subjected to 2-DE. As shown in Fig. 5, several bands appeared in the $\mathrm{pH}$ range of 5.5 to 6.5 , and 2 -DE of $2 \%$
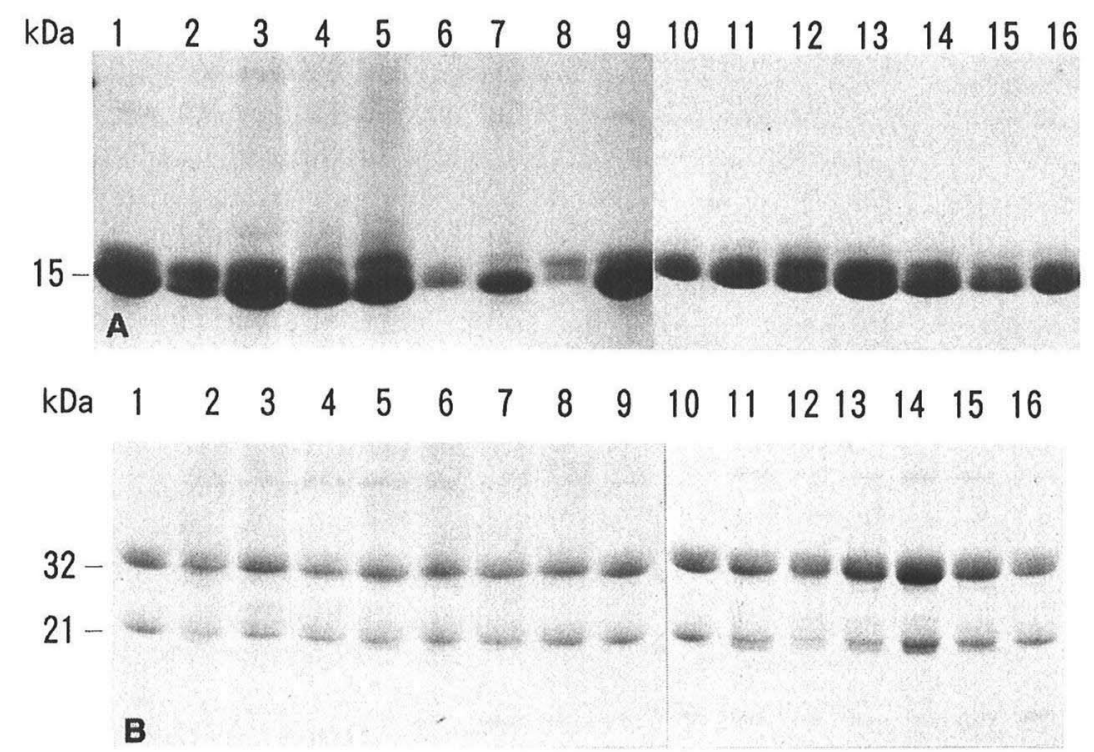

Fig. 4. SDS-PAGE of $55 \%$ propanol-soluble prolamin (A) and $2 \%$ SDS-soluble glutelin (B) from ancient ( $8 \mathrm{cv}$.*) and modern (7 cv.) rice cultivars: 1, Kinuhikari; 2, 10, Koshihikari; 3, Takasago-mochi; 4, Mangetsu-mochi; 5, Aizen-mochi; 6, Kuromochi*; 7, Akita-kuro*; 8, Murasaki-kuro*; 9, Kuro-73*; 11, Midorimai*; 12, Bluebonnet; 13, Mitsuyou-23; 14, Kaorieigou*; 15, Kaori-mochi*; 16, Kunitsukasa-chukann*. 


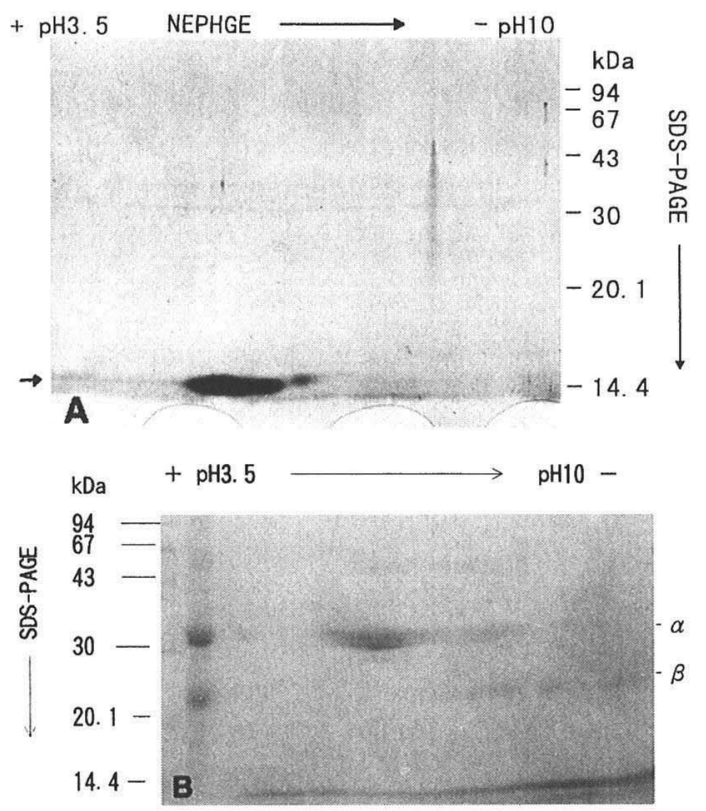

Fig. 5. Two-dimensional gel electrophoresis of $55 \%$ propanol-soluble prolamin (A) and 2\% SDS-soluble glutelin (B) from Akita-kuro. A sample protein was dissolved $(1 \mathrm{mg} / 100 \mu \mathrm{L})$ in the lysis buffer (18) and $20 \mu \mathrm{L}$ of the supernatant was applied to a vertical gel. The first dimension was conducted by isoelectrofocusing with a pH of 3.5-10 ampholine. The second dimension was done by SDS-PAGE in $15 \%$ polyacrylamide gel.

Table 3. Comparison of prolamin and glutelin contents in 12 ancient rice cultivars ${ }^{\mathrm{a}}$.

\begin{tabular}{|c|c|c|c|}
\hline \multirow{2}{*}{$\begin{array}{c}\text { Rice } \\
\text { cultivar }\end{array}$} & \multicolumn{2}{|c|}{$\begin{array}{l}\text { Percentage of } \\
\text { total protein }\end{array}$} & \multirow{2}{*}{$\begin{array}{l}\text { Total protein } \\
\text { content }(\%)^{\mathrm{b}}\end{array}$} \\
\hline & Prolamin & Glutelin & \\
\hline Midorimai & 5.5 & 88.4 & 6.9 \\
\hline Benimiyako & 5.8 & 81.2 & 7.3 \\
\hline Takaramitsu & 4.7 & 79.0 & 7.5 \\
\hline Kaori-eigou & 4.1 & 73.9 & 7.8 \\
\hline Kaori-mochi & 4.2 & 82.9 & 8.5 \\
\hline Benihikari & 5.3 & 90.1 & 8.5 \\
\hline Akita-kuro & 6.2 & 87.5 & 8.8 \\
\hline Kunitsukasa-chukann & 7.4 & 86.7 & 8.9 \\
\hline Mangetsu-mochi & 6.6 & 82.6 & 9.6 \\
\hline Kuro-mochi & 7.8 & 88.6 & 9.6 \\
\hline Kuro-60 & 5.2 & 88.7 & 9.6 \\
\hline Tsushimazairai & 4.7 & 90.6 & 11.4 \\
\hline Hiyoku-mochi ${ }^{\mathrm{c}}$ & 3.3 & 81.6 & 7.6 \\
\hline Nobentadiablanco ${ }^{\mathrm{c}}$ & 4.4 & 78.7 & 7.9 \\
\hline Koshihikaric & 5.5 & 87.5 & 8.2 \\
\hline Akitakomachic & 3.0 & 88.6 & 9.2 \\
\hline Mitsuyou-23c & 3.9 & 78.9 & 10.7 \\
\hline
\end{tabular}

${ }^{\text {a }}$ Data are the means of triplicate determinations.

${ }^{b}$ Total protein content (\%) on a dry weight basis.

${ }^{\mathrm{c}}$ Modern rice cultivars.
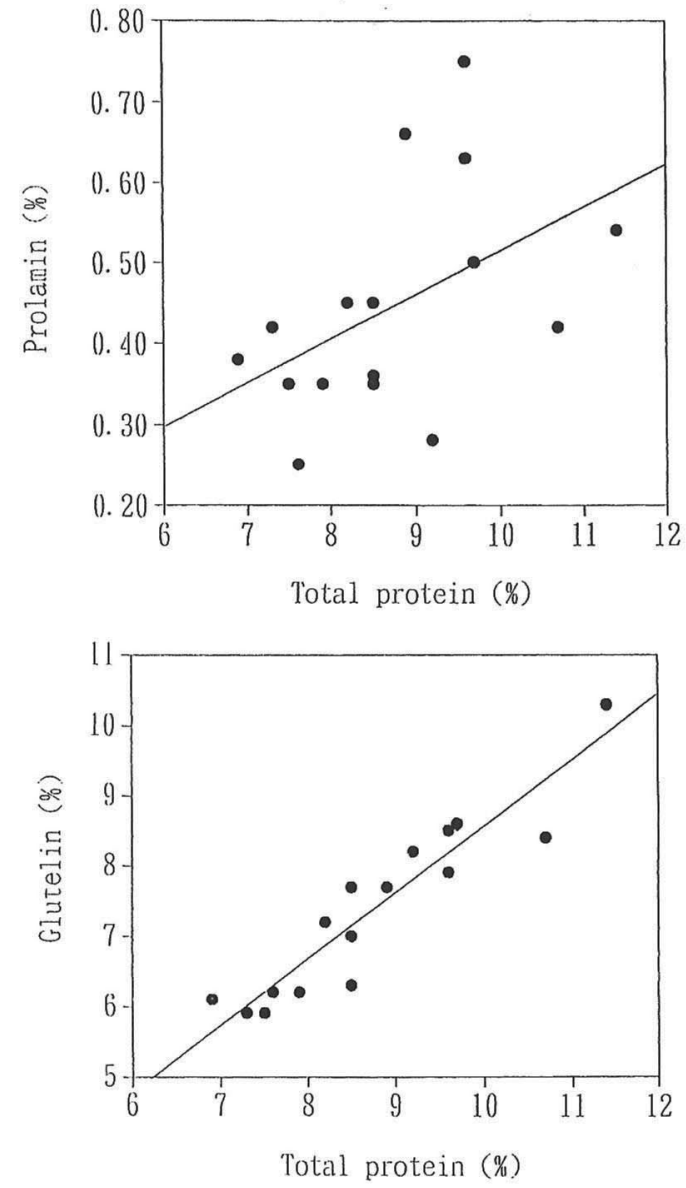

Fig. 6. Correlation between total protein and prolamin (above) or glutelin (below) extracted from ancient and modern rice cultivars. Regression lines were calculated by the least squares method barred on plots of prolamin $\left(Y=-2.93 \times 10^{-2}+5.43 \times 10^{-2} X, R^{2}=\right.$ $0.234)$ or glutelin $\left(Y=-0.907+0.947 X, R^{2}=0.875\right)$ against the total protein given in Table 3.

SDS-soluble glutelin revealed that two 21 and $32 \mathrm{kDa}$ bands were acidic and basic multicomponents, respectively (Fig. 5B). This heterogeneity coincided with previous observations by other workers $(18-20)$ irrespective of the extraction of glutelin with $0.1 \% \mathrm{NaOH}$ or $2 \%$ SDS. There was a relationship between the total protein and two storage proteins in the Kuromai (black rice) and Akamai (red rice) cultivars (Table 3). The recovery of prolamin also varied 3.0 to $7.8 \%$ with total protein contents ranging from 6.9 to $11.4 \%$, but there was no or little correlation between them as shown in Fig. 6A. On the contrary, glutelin accounted roughly for an increase in the total protein content (Fig. 6B). The ratio of prolamin to glutelin was $4.9: 78.1$ for 12 ancient cultivars, being in fair agreement with those reported by Cagampang et al. (26). The protein content in the modern rice cultivars was nearly as much as in the ancient cultivars.

Amino acid compositions of prolamin and glutelin from six ancient rice cultivars

Amino acid compositions of the prolamin and glutelin fractions from 6 ancient rice cultivars including 3 Kuromai and 3 Akamai lines are shown in Tables 
Table 4. Amino acid composition of 55\% propanolsoluble prolamin ${ }^{\mathrm{a}}$ from 6 ancient rice cultivars.

\begin{tabular}{|c|c|c|c|c|c|c|}
\hline \multirow{2}{*}{$\begin{array}{c}\text { Amino } \\
\text { acid }\end{array}$} & \multicolumn{3}{|c|}{ Kuromai $^{b}$} & \multicolumn{3}{|c|}{ Akamai $^{\mathrm{c}}$} \\
\hline & $\mathrm{K}_{1}$ & $\mathrm{~K}_{2}$ & $\mathrm{~K}_{3}$ & $A_{1}$ & $\mathrm{~A}_{2}$ & $A_{3}$ \\
\hline & \multicolumn{6}{|c|}{$\mathrm{mol} \%$} \\
\hline$A s x^{d}$ & 6.3 & 5.7 & 4.2 & 6.5 & 6.2 & 5.9 \\
\hline Thr & 2.6 & 3.6 & 4.1 & 2.4 & 2.6 & 2.2 \\
\hline Ser & 5.7 & 5.9 & 7.0 & 5.5 & 5.6 & 5.5 \\
\hline Glx $^{\mathrm{d}}$ & 21.1 & 20.7 & 24.5 & 21.9 & 21.1 & 26.5 \\
\hline Pro & 3.6 & 4.4 & 6.0 & 4.9 & 5.8 & 4.4 \\
\hline Gly & 6.1 & 8.3 & 5.0 & 5.6 & 5.7 & 5.5 \\
\hline Ala & 10.7 & 12.4 & 9.4 & 9.9 & 9.9 & 9.3 \\
\hline Val & 7.1 & 7.4 & 6.7 & 7.3 & 7.1 & 6.8 \\
\hline Cys & 0.1 & 0.3 & 1.5 & 0.1 & 0.1 & 0.1 \\
\hline Met & 0.0 & 0.1 & 1.0 & 0.0 & 0.1 & 0.1 \\
\hline Ile & 5.2 & 5.6 & 5.1 & 5.2 & 5.2 & 4.7 \\
\hline Leu & 14.2 & 12.7 & 10.8 & 13.9 & 13.5 & 12.8 \\
\hline Tyr & 5.8 & 0.9 & 4.2 & 5.7 & 5.9 & 5.6 \\
\hline Phe & 5.3 & 5.2 & 5.3 & 5.3 & 5.1 & 4.9 \\
\hline Lys & 0.4 & 1.2 & 0.2 & 0.1 & 0.3 & 0.2 \\
\hline His & 1.2 & 1.2 & 1.3 & 1.1 & 1.2 & 1.1 \\
\hline Arg & 4.7 & 4.2 & 3.8 & 4.7 & 4.7 & 4.6 \\
\hline \multicolumn{7}{|l|}{ Protein } \\
\hline content $^{\mathrm{e}}$ & 9.64 & 8.90 & 9.58 & 8.66 & 8.50 & 8.87 \\
\hline
\end{tabular}

${ }^{\mathrm{a}}$ Data (in $\mathrm{mol} \%$ ) are the means of duplicate determinations.

${ }^{\mathrm{b}}$ Kuromai (black rice lines), K1-K3: Akita-kuro, Murasakikuro and Kuro-mochi.

${ }^{\mathrm{c}}$ Akamai (red rice lines), A1-A3: Takaramitsu, Benimiyako and Kunitsukasa-chukann.

${ }^{\mathrm{d}}$ Aspartate plus asparagine and glutamate plus glutamine, respectively.

e Total protein content (\%) on a dry weight basis.

4 and 5. The prolamin fraction contained glutamate plus glutamine, alanine and leucine at high levels, but lysine and sulfur amino acids at low levels. The glutelin fraction was also characteristic of rice in this respect as described previously $(6,23,24,26)$. As a matter of course, there was no difference in amino acid composition between Kuromai and Akamai rice lines. When a comparison was made between the highest and lowest values of a given amino acid concerning the above ancient varieties according to the procedure of Kennedy and Schelstraete (27), the difference was to be much greater in prolamin than in glutelin; for example, in Table 4, the greatest difference was found with respect to Tyr in $A_{2}$, where the highest value $(5.9 \mathrm{~mol} \%$ ) among the six varieties was 6.56 -fold greater than the lowest value $(0.9 \mathrm{~mol} \%)$ in $\mathrm{K}_{2}$. With respect to $\mathrm{Thr}$ in $\mathrm{K}_{3}$, the highest value $(4.1 \mathrm{~mol} \%)$ among the six varieties was 1.86 -fold greater than the lowest $(2.2 \mathrm{~mol} \%)$ in $A_{3}$. The same over-rate was found with respect to Pro (the highest $6.0 \mathrm{~mol} \%$ in $\mathrm{K}_{3}$, and the lowest $3.6 \mathrm{~mol} \%$ in $\left.\mathrm{K}_{1}\right)$. Additionally, the highest value for Gly $(8.3 \mathrm{~mol} \%$ in $\mathrm{K}_{2}$ ) was 1.67-fold greater than the lowest value ( $5.0 \mathrm{~mol} \%$ in $\mathrm{K}_{3}$ ), and the highest value for Asx (6.5 mol\% in $A_{1}$ ) was 1.55 -fold greater than the lowest value $\left(4.2 \mathrm{~mol} \%\right.$ in $\mathrm{K}_{3}$ ). The differences were found with
Table 5. Amino acid composition of $2 \%$ SDS-soluble glutelin $^{\text {a }}$ from 6 ancient rice cultivars.

\begin{tabular}{|c|c|c|c|c|c|c|}
\hline \multirow{2}{*}{$\begin{array}{c}\text { Amino } \\
\text { acid }\end{array}$} & \multicolumn{3}{|c|}{ Kuromai $^{b}$} & \multicolumn{3}{|c|}{ Akamai $^{\mathrm{c}}$} \\
\hline & $\mathrm{K}_{1}$ & $\mathrm{~K}_{2}$ & $\mathrm{~K}_{3}$ & $\mathrm{~A}_{1}$ & $\mathrm{~A}_{2}$ & $\mathrm{~A}_{3}$ \\
\hline & \multicolumn{6}{|c|}{$\mathrm{mol} \%$} \\
\hline$A s x^{d}$ & 8.2 & 8.7 & 8.4 & 7.7 & 8.0 & 8.0 \\
\hline Thr & 4.0 & 4.5 & 5.8 & 3.8 & 4.4 & 3.9 \\
\hline Ser & 6.4 & 6.2 & 6.5 & 7.1 & 6.6 & 6.8 \\
\hline $\mathrm{Glx}^{\mathrm{d}}$ & 17.9 & 17.7 & 17.3 & 17.4 & 17.1 & 18.7 \\
\hline Pro & 5.8 & 4.3 & 7.0 & 6.2 & 5.6 & 4.6 \\
\hline Gly & 8.3 & 8.8 & 8.0 & 7.9 & 9.0 & 7.8 \\
\hline Ala & 8.4 & 7.7 & 7.2 & 7.0 & 8.2 & 8.5 \\
\hline Val & 7.2 & 7.2 & 7.0 & 7.0 & 6.8 & 7.1 \\
\hline Cys & 0.3 & 0.2 & 0.2 & 0.2 & 0.2 & 0.1 \\
\hline Met & 0.2 & 0.2 & 0.3 & 0.3 & 0.2 & 0.1 \\
\hline Ile & 4.9 & 5.3 & 4.7 & 5.0 & 4.8 & 5.1 \\
\hline Leu & 8.7 & 8.4 & 7.8 & 9.1 & 8.1 & 9.4 \\
\hline Tyr & 2.6 & 2.6 & 2.3 & 3.4 & 2.7 & 2.6 \\
\hline Phe & 5.1 & 5.4 & 5.0 & 5.2 & 4.8 & 5.2 \\
\hline Lys & 2.8 & 3.4 & 3.5 & 2.6 & 3.3 & 2.5 \\
\hline His & 1.8 & 1.9 & 2.0 & 2.1 & 2.2 & 2.0 \\
\hline Arg & 7.5 & 7.6 & 7.1 & 7.2 & 8.1 & 7.5 \\
\hline \multicolumn{7}{|l|}{ Protein } \\
\hline content $^{\mathrm{e}}$ & 9.64 & 8.90 & 9.58 & 8.66 & 8.50 & 8.87 \\
\hline
\end{tabular}

${ }^{\text {a }}$ Data (in mol\%) are the means of duplicate determinations.

${ }^{\mathrm{b}} \mathrm{K}_{1}-\mathrm{K}_{3}$ are ibidem in Table 4.

${ }^{\mathrm{c}} \mathrm{A}_{1}-\mathrm{A}_{3}$ are ibidem in Table 4.

${ }^{\mathrm{d}}$ Being ibidem in Table 4.

e Total protein content (\%) on a dry weight basis.

respect to Cys and Met, which were minor amino acids of prolamin. Taken altogether, in the prolamin fraction, differences over $30 \%$ between the highest and lowest values were observed for 10 amino acids such as Met, Cys, Lys, Tyr, Thr, Pro, Gly, Asx, Ala and Leu. Alternatively, in the glutelin fraction (Table 5), only 4 amino acids including Pro (63\%), Thr (53\%), Thy $(48 \%)$ and Lys $(40 \%)$ exhibited a difference over $30 \%$ for the other 11 amino acids, except Met and Cys, where differences averaged 14\%. Met and Cys ranged from 0.1 to $0.3 \mathrm{~mol} \%$ of glutelin, thus it was difficult to calculate the precise value.

\section{REFERENCES}

1) Goodrich AG. 1987. Dietary regulation of gene expression: enzymes involved in carbohydrate and lipid metabolism. Annu Rev Nutr 7: 157-185.

2) Izumi H, Adachi T, Fujii N, Matsuda M, Nakamura R. 1992. Nucleotide sequence of a major allergenic protein in rice seeds. FEBS Lett. 302: 213-216

3) Osaka K. 1993. Ancient rice. Shokuseikatsu-kenkyu 14(6): 12-19 (in Japanese).

4) Ogawa N. 1993. Fundamental studies on characterization of red rice. Shokuseikatsu-kenkyu 14(4): 4-10 (in Japanese).

5) Shewry PR, Miflin BJ. 1985. Seed storage proteins of economically important cereals. Adv Cereal Sci Technol VII: $1-84$.

6) Juliano BO. 1972. The rice caryopsis and its composi- 
tion. In: Rice Chemistry and Techonology (Houston DF, ed), p 16-74. Association of Cereal Chemists Inc., St. Paul, MN.

7) Kim WT, Okita TW. 1988. Structure, expression, heterogeneity of the rice seed prolamines. Plant Physiol 88: 649-655.

8) Li X, Okita TW. 1988. Accumulation of prolamines and glutelins during rice seed development: a quantative evaluation. Plant Cell Physiol 34: 358-390.

9) Ogawa M, Kumamaru T, Satoh H, Iwata N, Omura T, Kasai Z, Tanaka K. 1987. Purification of protein body-I of rice seed and its polypeptide composition. Plant Cell Physiol 28: 1517-1527.

10) Sugimoto T, Tanaka Y, Kasai Z. 1986. Improved extractions of rice prolamin. Agric Biol Chem 50: 2409-2411.

11) Hibino T, Kidzu K, Masumura T, Ohtsuki K, Tanaka K, Kawabata M, Fujii S. 1989. Amino acid composition of rice prolamin polypeptides. Agric Biol Chem 53: 513518.

12) Udaka J, Takumi K, Tsuji H, Ogawa T, 1996. Accumulation of proteins and polypeptide composition of the glutelin in ancient cultivars of rice seed. J Home Econ Jpn 47: 755-763.

13) Laemmli UK. 1970. Cleavage of structural proteins during the assembly of the head of bacteriophage T4. Nature 227: 680-685.

14) O'Farrel PZ, Goodman HM, O'Farrel PH. 1977. High resolution two-dimensional electrophoresis of basic as well as acidic proteins. Cell 12: 1133-1142.

15) Association of Official Agricultural Chemists. 1980. Official Methods of Analysis. Washington, D. C., 858 pp.

16) Lowry OH, Rosebrough NJ, Farr AL, Randall RJ. 1951. Protein measurement with the Folin phenol reagent. J Biol Chem 193; 265-275.

17) Kim WT, Krishnan HB, Okita TW. 1986. Molecular studies on the rice storage proteins. Rice Genetic Newsletter 33: 100-101.

18) Yamagata H, Sugimoto T, Tanaka Y, Kasai Z. 1982. Biosynthesis of storage proteins in developing rice seeds. Plant Physiol 70: 1094-1100.

19) Luthe DS. 1983. Storage protein accumulation in developing rice (Oryza sativa L.) seeds. Plant Sci LETT. 32: $147-158$

20) Zhao WM, Gatehouse JA, Boulter D. 1983. The purification and partial amino acid sequence of a polypeptide from the glutelin fraction of rice grains: homology to pea legumin. FEBS Lett. 162: 96-102.

21) Juliano BO, Boulter D. 1976. Extraction and composition of rice endosperm glutelin. Phytochem 15: 16011606.

22) Robert LS, Nozzolio C. 1983. Total solubilization of groat protein in high protein oat (Avena sativa L. cv. Hinoat): evidence that glutelins are a minor component. Can Inst Food Sci Technol J 16: 196-200.

23) Horikoshi M, Kobayashi H, Yamazoe Y, Mikami B, Morita Y. 1991. Purification and complete amino acid sequence of a major prolamin of rice endosperm. $J$ Cereal Sci 14: 1-14.

24) Padhye VW, Salunkhe DK. 1979. Extraction and characterization of rice proteins. Cereal Chem 56: 389-393.

25) Krishnan HB, Okita TW. 1986. Structural relationship among the rice glutelin polypeptides. Plant Physiol 81: 748-753.

26) Cagampang GB, Cruz LJ, Espiritu SG, Santrigo RG, Juliano BO. 1966. Studies on the extraction and composition of rice protein. Cereal Chem 43: 145-155.

27) Kennedy BM, Schelstraete M. 1974. Chemical, physical, and nutritional properties of high-protein flours and residual kernel from the overmilling of uncoated milled rice. II. Amino acid comparison and biological evaluation of the protein. Cereal Chem 51: 448-457. 